\title{
PENGARUH PEMBERIAN PUPUK ORGANIK CAIR NIRA AREN (Arenga pinnata MERR) TERHADAP PERTUMBUHAN TANAMAN KANGKUNG DARAT (ipomea reptans POIR)
}

\section{THE INFLUENCE OF GIVING LIQUID ORGANIC FERTILIZER PALM SUGAR (Arenga pinnata MERR) TO THE GROWTH OF LAND WATER KALE PLANTS (Ipomea reptans POIR)}

\author{
Lukman $^{1^{*}}$ \\ Program Studi Agroteknologi Sekolah Tinggi Ilmu Pertanian Mujahidin Tolitoli 94514, Indonesia
}

\begin{abstract}
ABSTRAK
Penelitian ini bertujuan untuk mengetahui pengaruh pertumbuhan tanaman kangkung darat akibat pemberian pupuk organik cair nira aren dan untuk mengetahui konsentrasi POC nira aren yang tepat terhadap pertumbuhan tanaman kangkung darat. Penelitian ini menggunakan Rancangan Acak Kelompok Faktor tunggal terdiri dari 4 ulangan 4 perlakuan. Hasil Penelitian terbaik terhadap tinggi tanaman dan jumlah daun, panjang daun serta lebar daun umur 14 dan 24 HST rata-rata dipengaruhi pada penggunaan nira aren $40 \mathrm{ml} / \mathrm{L}$ air dengan tinggi $19,59 \mathrm{~cm}$ dan $32,13 \mathrm{~cm}$ jumlah daun 6,34 dan 12,25 helai, panjang daun 13,71 dan 15,75 sedangkan lebar daun 1,74 dan $3,48 \mathrm{~cm}$.
\end{abstract}

Katakunci: POC, pertumbuhan, kangkung darat.

\section{ABSTRACT}

This study aims to determine to determine the effect of land spinach plant growth due to the provision of liquid organic fertilizer palm sugar and to determine the right concentration of palm sugar palm POC to the growth of land spinach plants. This experiment used a single factor randomized block design consisting of 4 replications of 4 treatments. The best experimental results on plant height and number of leaves, leaf length and leaf width aged 14 and 24 HST were influenced by the use of palm juice $40 \mathrm{ml} / \mathrm{L}$ water with a height of $19.59 \mathrm{~cm}$ and $32.13 \mathrm{~cm}$ number of leaves 6.34 and 12.25 strands, leaf length 13.71 and 15.75 while leaf widths are 1.74 and $3.48 \mathrm{~cm}$.

Keywords: POC, growth, ipomea reptans.

\section{Pendahuluan}

Tanaman kangkung darat termasuk tanaman sayuran yang berumur pendek. Manfaat daunnya mempunyai peran penting terhadap sumber pangan di Indonesia (Agung, 2007). Kandungan gizi dalam 100 gram kangkung meliputi energi sebesar $29 \mathrm{kal}$; protein 3 gram; lemak 0,3 gram; karbohidrat 5,4 gram; serat 1 gram; kalsium $73 \mathrm{mg}$; fosfor $50 \mathrm{mg}$; besi $2,5 \mathrm{mg}$; vitamin A $6.300 \mathrm{IU}$; vitamin B1 $0,07 \mathrm{mg}$; Vitamin C $32 \mathrm{mg}$; Air 89,7 gram (Harjana, 2016).

Kangkung darat memiliki warna hijau yang pekat, atau memiliki klorofil yang tinggi. Sayuran yang berwarna hijau merupakan sumber

\footnotetext{
${ }^{*}$ Penulis Korespondensi

E-mail: lukman.arif02@yahoo.com

Telp: $+62-82291621880$
}

pigmen, mineral, dan vitamin terbaik dan penting bagi kesehatan manusia. Klorofil mampu berfungsi sebagai pembersih alamiah (mendorong terjadinya detoksifikasi); antioksidan, antipenuaan dan antikanker (Kurniawan, 2007). Salah satu faktor budidaya tanaman kangkung darat yang perlu diperhatikan adalah pemberian unsur hara atau pemupukan untuk menyuburkan tanaman.

Untuk menyediakan unsur hara tersebut perlu dilakukan pemupukan, selain pemupukan dari luar, tanah telah menyediakan hara dan mineral yang cocok untuk tanaman. Namun, dalam jangka panjang persediaan hara dalam tanah semakin berkurang akibatnya terjadi ketidakseimbangan antara penyerapan hara yang cepat dengan pembentukan hara yang lambat. Oleh karena itu, pemupukan merupakan suatu 


\section{Jurnal agrotech 8 (2) 50-55}

keharusan dalam sistem pertanian (Setiawan, 2005).

Penggunaan pupuk anorganik secara terus menerus akan berdampak negatif terhadap produktivitas tanah. Karena itu, memupuk tanaman lebih dianjurkan menggunakan pupuk organik. Pupuk organik merupakan pupuk yang berperan meningkatkan aktifitas biologi, kimia, dan fisik tanah sehingga tanah menjadi subur dan baik untuk pertumbuhan tanaman. Pupuk organik dapat berupa kompos, pupuk kandang, pupuk hijau dan pupuk organik cair. Bahan baku pupuk organik sangat mudah diperoleh karena dapat memanfaatkan sampah organik yang berada disekitar lingkungan kita. Pupuk organik cair merupakan pupuk yang berasal dari pelapukan bahan bahan organik berupa sisa-sisa tanaman dan kotoran hewan, atau berasal dari ektraksi tanaman, sintetis kimia serta fermentasi mikroba (Qiong Shi, et.al., 2017. Hadisuwito 2007). Pemupukan melalui daun merupakan cara yang sangat efisien, karena nutrisi dengan mudah menembus stomata maupun kutikula daun dan masuk kedalam sel (Baldi and Toselli. 2013 ) Sejalan dengan pemikiran diatas, maka telah dilakukan penelitian tentang pengaruh pemberian pupuk organik cair nira aren (Arenga pinnata MERR) terhadap pertumbuhan dan hasil tanaman kangkung darat (Ipomea reptans Poir).

Penelitian ini bertujuan untuk untuk mengetahui pengaruh pertumbuhan tanaman kangkung darat akibat pemberian pupuk organik cair nira aren serta untuk mengetahui konsentrasi POC nira aren yang tepat terhadap pertumbuhan tanaman kangkung darat.

\section{Metode Penelitian}

Penelitian ini telah dilaksanakan di Desa Kalangkangan, Kecamatan Galang Kabupaten Tolitoli, pada bulan Maret sampai bulan April 2018. Alat dan bahan yang digunakan adalah sebagai berikut : Cangkul, Gayung, Penggaris, Gelas ukur 100 ml, Pisau , Timbangan, , Nampan 1 buah, Bahan yang digunakan berupa Bibit tanaman kangkung (Ipomea reptans Poir) yang diperoleh dari salah satu Toko Pertanian, POC Nira aren, dan Pupuk kandang sapi sebagai pupuk dasar. Populasi, Sampel dan Teknik Pengambilan sampel

Populasi adalah seluruh tanaman kangkung yang digunakan pada penelitian adapun teknik pengambilan sampel adalah sebagai berikut:

a. Tinggi Tanaman $(\mathrm{cm})$ Tinggi tanaman diukur dari pangkal batang di atas permukaan tanah sampai titik tumbuh
e-ISSN : 2621-7236

p-ISSN : 1858-134X

menggunakan benang kemudian diukur kembali menggunakan mistar agar didapat hasil pengukuran yang lebih akurat. Pengukuran dilakukan pada umur 14, dan 28 hari setelah tanam (HST)

b. Jumlah daun (helai) Untuk pengamatan jumlah daun dilakukan dengan cara menghitung banyaknya daun yang telah terbuka sempurna setelah tanaman berumur, 14, dan 28 hari setelah tanam (HST)

c. Lebar Daun ( $\mathrm{cm}$ ) Untuk pengamatan lebar permukaan daun dilakukan dengan mengukur pada bagian tengah daun.cara menghitung panjang daun (dari pangkal tangkai daun hingga ujung daun sepanjang tulang daun) setelah tanaman berumur 14, dan 28 hari setelah tanam (HST)

d. Panjang daun $(\mathrm{cm})$ cara menghitung panjang daun (dari pangkal tangkai daun hingga ujung daun sepanjang tulang daun) setelah tanaman berumur 14 dan 28 hari setelah tanam (HST)

\section{Analisis Data}

Penelitian yang dilakukan adalah penelitian satu faktor dengan menggunakan rancangan acak kelompok (RAK). Perlakuan diatur dengan pengacakan secara lengkap sehingga setiap satuan percobaan memiliki peluang yang sama untuk mendapatkan setiap perlakuan

$$
\begin{aligned}
& Y i j=\mu+\tau i+\beta j+\varepsilon i j \\
& Y i j: \text { pengamatan pada perlakuan ke-i } \\
& \text { dan kelompok ke-j } \\
& \mu: \text { rataan umum } \\
& i: \text { pengaruh perlakuan ke-i } \\
& \beta j: \text { pengaruh kelompok ke-j } \\
& \varepsilon i j \text { : pengaruh acak pada perlakuan } \\
& \text { ke-i kelompok ke-j }
\end{aligned}
$$

Dalam penelitian ini terdapat 4 perlakuan dan 4 pengulangan, perlakuan yang diberikan adalah :

$\mathrm{P} 0=100 \mathrm{ml}$ air $(0 \%$ pupuk organik cair atau tanpa POC).

$\mathrm{P} 1=20 \mathrm{ml}$ pupuk organik cair Nira aren/ liter air $\mathrm{P} 2=40 \mathrm{ml}$ pupuk organik cair Nira aren /liter air P3 = $60 \mathrm{ml}$ pupuk organik cair Nira aren /liter air

Apabila hasil analisis ragam memberikan pengaruh yang nyata, maka akan diuji lanjut dengan BNJ 5\%.

\section{Pelaksanaan Penelitian}

Dalam pelaksanaan penelitian terlebih dahulu pengolahan tanah dan persiapan lahan pengolahan tanah awal dilakukan 2 (dua) minggu 


\section{Jurnal Agrotech 8 (2) 50-55}

sebelum tanam dengan menggunakan cangkul, selanjutnya dibuat petakan ukuran 2,0 m x 1,0 m sebanyak 24 petak, jarak antar petakan $40 \mathrm{~cm}$ dan jarak antar ulangan $50 \mathrm{~cm}$. kemudian tanah digemburkan serta dicampur dengan pupuk kandang sapi sebagai pupuk dasar.

Sebelum dilakukan penanaman, terlebih dahulu benih kangkung direndam dengan air kemudian dipisahkan dengan benih yang mengapung, benih yang tenggelam diambil sebagai bibit dan diperam selama $2 \times 24$ jam, setelah akar keluar benih tersebut langsung ditanam ke setiap bedengan, masing-masing 3 biji per lubang tanam. selanjutnya pengaplikasian pupuk percobaan yaitu dilakukan 7 Hari Setelah Tanam, kemudian 14 dan 28 HST. dengan cara disemprotkan sesuai dosis percobaan. Pemeliharaan Tanaman, yaitu kelembapan tanah tetap, dengan melakukan penyiraman pagi dan sore hari, untuk pengendalian gulma dilakukan dengan cara di cabut, sedangkan untuk mengendalian hama diberikan racun organik seperti bio Insect.

\section{Hasil dan Pembahasan}

\section{Tinggi Tanaman}

Hasil pengamatan terhadap pertumbuhan tinggi tanaman disajikan pada pengamatan 14 HST dan 24 HST, tanaman tertinggi diperoleh pada perlakuan P2 (POC nira aren $40 \mathrm{ml} \mathrm{L}^{-1}$ ), diikuti perlakuan P3 (POC nira aren $60 \mathrm{ml} \mathrm{L}^{-1}$ ), dan P1 (POC nira aren $20 \mathrm{ml} \mathrm{L}^{-1}$ ), dan P0 (Kontrol) sedangkan laju pertumbuhan tinggi tanaman terendah diperoleh pada perlakuan P0 dan P1.

Hasil analisis sidik ragam bahwa tanaman kangkung dapat memberikan pengaruh nyata setelah tanaman berumur 14 HST dan 24 HST.

Tabel 1. Pengaruh Pemberian POC Nira Aren Terhadap Tinggi Tanaman Kangkung

\begin{tabular}{cccc}
\hline Perlakuan & \multicolumn{3}{c}{ Tinggi Tanaman } \\
\hline & $14 \mathrm{HST}$ & $24 \mathrm{HST}$ & BNJ \\
\hline P0 & $15.60 \mathrm{a}$ & $26.30 \mathrm{a}$ & \\
P1 & $18.57 \mathrm{~b}$ & $25.64 \mathrm{a}$ & $3.95 \%$ \\
P2 & $19.59 \mathrm{~b}$ & $32.13 \mathrm{~b}$ & \\
P3 & $19.31 \mathrm{~b}$ & $28.55 \mathrm{~b}$ & \\
\hline
\end{tabular}

Keterangan : Angka yang dikuti dengan huruf yang berbeda menunjukkan perbedaan yang nyata pada taraf 5\% menurut uji BNJ.
e-ISSN : 2621-7236

p-ISSN : 1858-134X

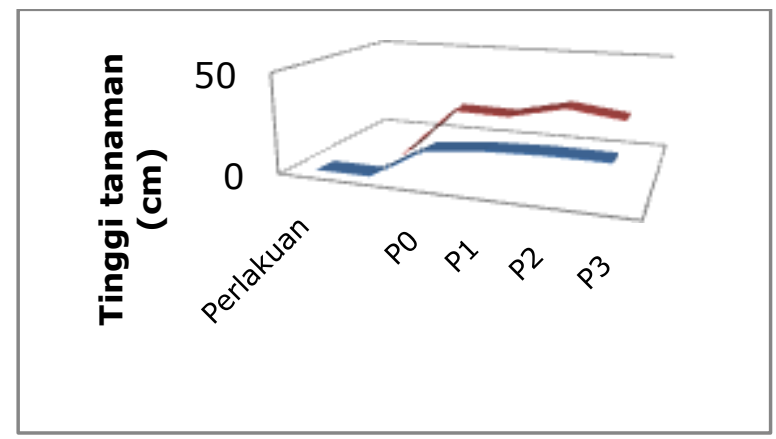

Gambar 1. Diagram pengaruh perlakuan terhadap tinggi tanaman umur 14 dan 25 HST

Pada gambar 1 diatas terlihat bahwa nilai paling tinggi pada perlakuan $40 \quad \mathrm{ml} \mathrm{L} \mathrm{L}^{-1}$ dibandingkan dengan perlakuan lainnya, akan tetapi masing-masing perlakuan tidak memberikan pengaruh yang sama, kecuali P0 atau kontrol, hal ini diduga diakibatkan bahwa tanaman kangkung umur 14 HST, telah merespon secara baik POC yang diberikan terhadap tanaman. selain itu hal ini disebabkan bahwa tanaman umur 24 HST dapat menyerap hara secara baik karena bagian tanaman telah tumbuh secara sempurna, misalnya akar maupun daun. Pupuk organik kaya akan unsur hara makro dan mikro, mampu menggemburkan tanah, meningkatkan aerasi tanah dan mengefisinkan penggunaan pupuk kimia. Sutejo (2002), mengemukakan bahwa nitrogen merupakan unsur hara utama untuk pertumbuhan bagian-bagian vegetatif tanaman.

\section{Jumlah Daun}

Hasil pengamatan terhadap jumlah daun tanaman kangkung umur 14 HST dan 24 HST, tanaman tertinggi diperoleh pada perlakuan P3 (POC nira aren $60 \mathrm{ml} \mathrm{L}^{-1}$ ), diikuti perlakuan $\mathrm{P} 2$ (POC nira aren $40 \mathrm{ml} \mathrm{L}^{-1}$ ), dan P1 (POC nira aren $20 \mathrm{ml} \mathrm{L}^{-1}$ ), dan P0 (Kontrol). Namun hasil analisis ragam pemberian POC nira aren tidak memberikan pengaruh terhadap jumlah daun.

Tabel 2. Pengaruh Pemberian POC Nira Aren Terhadap Jumlah daun Tanaman Kangkung

\begin{tabular}{cccc}
\hline Perlakuan & \multicolumn{2}{c}{ Jumlah Daun } & BNJ \\
\hline & 14 HST & 24 HST & \\
\hline P0 & 6.19 & 9.18 & \\
P1 & 6.26 & 10.07 & $3.95 \%$ \\
P2 & 6.34 & 12.25 & \\
P3 & 6.39 & 10.76 & \\
\hline
\end{tabular}

Keterangan : Angka yang dikuti dengan huruf yang berbeda menunjukkan perbedaan yang nyata pada taraf 5\% menurut uji BNJ. 
Jurnal Agrotech 8 (2) 50-55

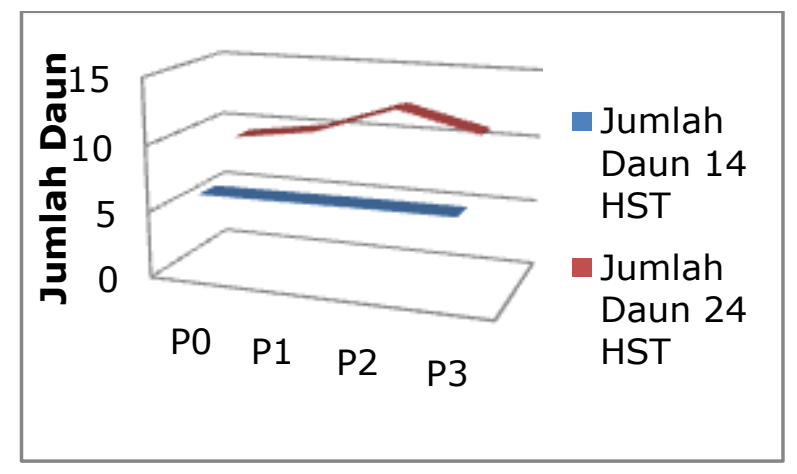

Gambar 2. Diagram pengaruh perlakuan terhadap Jumlah Daun tanaman umur 14 HST dan 24 HST

Meningkatnya jumlah dan luas daun tanaman kangkung yang diberi POC Nira aren disebabkan oleh ketersediaan hara nitrogen dan posfor yang meningkat. Nyakpa, et al. (1988) menyatakan bahwa proses pembentukan daun tidak terlepas dari peranan unsur hara seperti nitrogen dan fosfor yang terdapat pada tanah dan tersedia bagi tanaman. Kedua unsur ini berperan dalam pembentukan sel-sel baru dan komponen utama penyusun senyawa organik dalam tanaman seperti asam amino.

\section{Panjang Daun}

Hasil analisis sidik ragam pemberian POC nira aren terhadap panjang daun kangkung umur 14 HST memberikan pengaruh nyata, pengamatan panjang daun yang terpanjang yaitu pada perlakuan P2 (POC nira aren $40 \mathrm{ml} \mathrm{L}^{-1}$ ) dibandingkan dengan perlakuan lainnya. sedangkan pemberian POC nira aren pada umur 24 HST tidak memberikan pengaruh yang nyata, namun daun terpanjang terdapat pada perlakuan P2 (POC nira aren $40 \mathrm{ml} \mathrm{L}^{-1}$ ).

Tabel 3. Pengaruh Pemberian POC Nira Aren Terhadap Panjang daun Tanaman Kangkung

\begin{tabular}{cccc}
\hline Perlakuan & \multicolumn{2}{c}{ Panjang Daun $(\mathrm{cm})$} & \multirow{2}{*}{ BNJ } \\
\cline { 1 - 3 } & 14 HST & $24 \mathrm{HST}$ & \\
\hline P0 & $12.91 \mathrm{a}$ & 13.20 & \\
P1 & $12.765 \mathrm{a}$ & 13.68 & \multirow{2}{*}{$3.95 \%$} \\
P2 & $13.71 \mathrm{~b}$ & 15.76 & \\
P3 & $12.745 \mathrm{a}$ & 14.13 & \\
\hline
\end{tabular}

Keterangan : Angka yang dikuti dengan huruf yang berbeda menunjukkan perbedaan yang nyata pada taraf $5 \%$ menurut uji BNJ.

Pengamatan daun terpanjang terdapat pada perlakuan P2 (40 ml. $\left.{ }^{\mathrm{L}-1}\right)$ dengan tinggi 13,71 $\mathrm{cm}$, hal ini diduga bahwa pada dosis yang diberikan tersebut dapat diserap dengan baik oleh
e-ISSN : 2621-7236

p-ISSN : 1858-134X

daun tanaman kangkung. POC nira aren mengadung unsur hara $\mathrm{N}, \mathrm{P}, \mathrm{K}$ dan $\mathrm{Ca}$ (Lukman et,al.,2017). Hasil analisis ragam tidak memberikan pengaruh yang nyata terhadap perpanjangan daun umur $24 \mathrm{HST}$, hal ini diduga tanaman kangkung umur 24 HST telah berhenti fase pertumbuhan sel yang signifikan, kisaran pertumbuhan $13,20 \mathrm{~cm}$ sampai dengan $15,76 \mathrm{~cm}$.

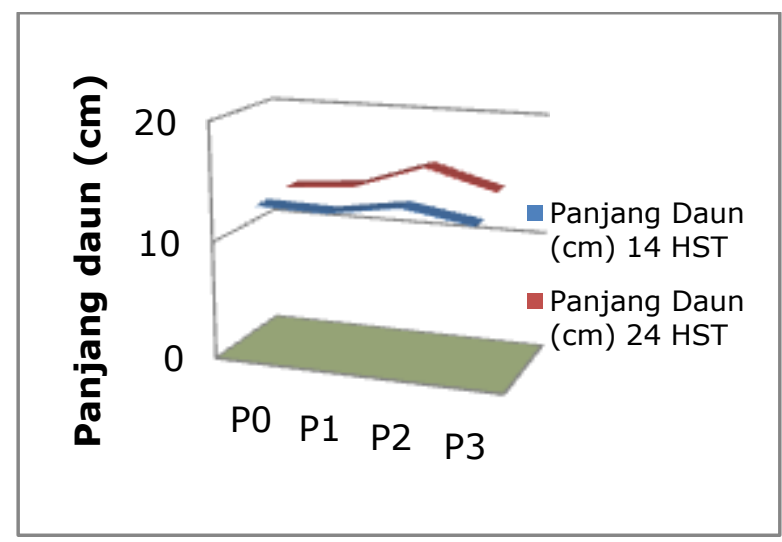

Gambar 3. Diagram pengaruh perlakuan terhadap Lebar Daun tanaman umur 14 HST dan 24 HST

Pada awal perkembangan daun, aktifitas meristem daun menyebabkan terjadinya perpanjangan daun. Perpanjangan daun berikutnya terjadi sebagai akibat aktifitas meristem interkalar. meristem interkalar adalah meristem yang terdapat diantara meristem primer dan jaringan dewasa. Meristem semacam ini dijumpai pada tumbuhan yang batangnya beruas-ruas, misalnya keluarga rumput-rumputan. Pemanjangan ruas terjadi karena proses pembelahan sel membentuk sel-sel sejajar dan sel-sel muda yang menjadikan ruas makin membentang dan bertambah panjang. (Artikelsiana, 2018).

\section{Lebar Daun}

Hasil analisis ragam pengaruh penggunaan POC nira aren terhadap lebar daun tanaman kangkung umur 14 HST tidak memberikan pengaruh nyata, namun daun terlebar terdapat pada pemberian nira aren $40 \mathrm{ml} . \mathrm{L}-1$ air, yaitu $1.74 \mathrm{~cm}$, selanjutnya untuk lebar daun umur 24 HST, hasil amalisis ragam memberikan pengaruh nyata yaitu pada perlakuan P2 (40 ml. $\mathrm{L}^{-1}$ air). hai dapat dilihat pada table 4. Lingga dan Marsono (2005) menyatakan bahwa dosis pupuk yang tepat merupakan salah satu pertimbangan dalam pertumbuhan tanaman, antara lain adalah lebar daun. peningkatan unsur hara seperti nitrogen, posfor, kalium dimana unsur 


\section{Jurnal Agrotech 8 (2) 50-55}

nitrogen mempengaruhi pembentukan selsel baru, fosfor berperan dalam pengaktifan enzim-enzim dalam proses fotosintesis dan kalium mempengaruhi perkembangan jaringan meristem yang dapat mempengaruhi panjang dan lebar daun.

Tabel 4. Pengaruh Pemberian POC Nira Aren Terhadap Lebar daun Tanaman Kangkung

\begin{tabular}{|c|c|c|c|}
\hline Perlakuan & \multicolumn{2}{|c|}{ Lebar Daun $(\mathrm{cm})$} & \multirow{2}{*}{$\mathrm{BNJ}$} \\
\hline & $14 \mathrm{HST}$ & $24 \mathrm{HST}$ & \\
\hline P0 & 1.50 & $2.197 \mathrm{a}$ & \\
\hline $\mathrm{P} 1$ & 1.54 & $2.407 \mathrm{a}$ & $3.95 \%$ \\
\hline $\mathrm{P} 2$ & 1.74 & $3.48 \mathrm{~b}$ & \\
\hline P3 & 1.54 & $2.615 \mathrm{a}$ & \\
\hline
\end{tabular}

Keterangan : Angka yang dikuti dengan huruf yang berbeda menunjukkan perbedaan yang nyata pada taraf $5 \%$ menurut uji BNJ.

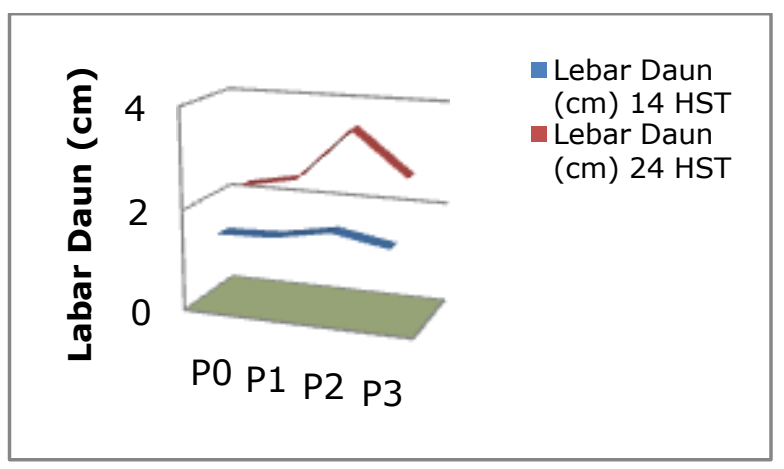

Gambar 4. Diagram pengaruh perlakuan terhadap Lebar Daun tanaman umur 14 HST dan 24 HST

Lakitan (1996) menyatakan bahwa tanaman yang tidak mendapat tambahan nitrogen akan tumbuh kerdil serta daun yang terbentuk lebih kecil, tipis dan jumlahnya akan sedikit sedangkan tanaman yang mendapatkan unsur nitrogen yang cukup maka daun yang terbentuk akan lebih banyak dan lebar. Daun merupakan organ vegetatif tanaman, jumlahnya sangat mempengaruhi pertumbuhan tanaman karena daun merupakan organ tempat terjadinya fotosintesis. Pelebaran daun (bifacial/dorsoventral) terjadi bila meristem tepi daun aktif melakukan pembelahan sel. Bila aktifitas meristem tepi tersebut terbatas hanya pada daerah-daerah tertentu saja, maka akan terbentuk daun yang berbagi menyirip atau majemuk menyirip. Jadi, pada dasarnya bentuk daun sangat tergantung dari perkembangannya, terutama pembelahan dan pembesaran sel (Artikelsiana, 2018).
e-ISSN : 2621-7236

p-ISSN : 1858-134X

\section{Kesimpulan}

Adapun kesimpulan dari penelitian ini adalah :

a. Penggunaan POC nira aren pada dosis 20 $\mathrm{ml}, \mathrm{L}^{-1}$ air sampai dengan $60 \mathrm{ml}, \mathrm{L}^{-1}$ air memberikan pengaruh terhadap tinggi tanaman, jumlah daun, panjang daun dan lebar daun tanaman kangkung darat (Ipomea reptans).

b. Tinggi tanaman, jumlah daun, panjang daun dan lebar daun umur 14 HST dan 24 HST rata-rata dipengaruhi oleh penggunaan POC nira aren $40 \mathrm{ml}, \mathrm{L}^{-1}$ air.

\section{Daftar Pustaka}

Agung, A.Oka. 2007. Pengaruh pemberian pupuk kascing terhadap pertumbuhan tanaman kangkung darat (ipomoea reptans poir). Jurnal sains mipa. Vol: 13. No: 1. Hal: 26

Artikelsiana, 2018 Pengertian Dan MacamMacam Jaringan Meristem (www//http diakses September 2018

Baldi E and M. Toselli. 2013 Root growth and Survivorship In Cow Manure And Compost Amended Soils, J,Plant Soil Environ, Vol. 59, No. 5: 221-226.

Hadisuwito, S. 2007. Membuat pupuk kompos cair. PT. Agromedia Pustaka. Jakarta. 51 hlm.

Harjana,. 2016. Kandungan gizi dan manfaat kangkung. Diakses pada 16 januari 2018, dari http//manfaatnya sehat. Blong spot.co.id

Kurniawan, R. 2007. Pengaruh Berbagai Media Tanam terhadap Pertumbuhan Bibit Andalas (Morus macrouna Miq). (Skripsi). Fakultas Pertanian Universitas Andalas Padang. 46 hal.

Lakitan, B. 1996. Fisiologi Pertumbuhan dan Perkembangan Tanaman. PT. Raja Grafindo Persada. Jakarta.

Lingga, P dan Marsono. 2005. Petunjuk Penggunaan Pupuk. Penebar Swadaya. Jakarta..

Lukman, S. Darman, I. Wahyudi,dan Ramlan 2016 Kajian Nira Aren (Arenga pinnata merr.) Sebagai Pupuk Organik Cair Terhadap Pertumbuhan Tanaman Padi the effect of arenga based liquid organic 


\section{Jurnal Agrotech 8 (2) 50-55}

fertilizer on rice plant growth, j. Agroland 23 (1) : 20 - 25

Manis, Supriadi, dan I. Said 2017 Pemanfaatan Limbah Kulit Pisang Sebagai Pupuk Organik Cair Dan Aplikasinya Terhadap Pertumbuhan Tanaman Kangkung Darat(Ipomea reptans poir) utilization of banana peel waste as an organic liquid fertilizer and its aplication on growth ofswamp cabbage land (Ipomea reptans poir) j. Akad. Kim. 6(4): 219-226,

Nyakpa, M. Y., AM Lubis, M. A. Pulung, A. G. Amroh, A. Munawar, G. B. Hong dan N. Hakim. 1988. Kesuburan Tanah. Universitas Lampung. Lampung

Santosa 2008 Ragam dan Khasiat Tanaman Obat. Jakarta : Agromedia Pustaka

Purwa, Petunjuk Pemupukan, Jakarta: PT Agromedia Pustaka, 2007, h. 33.

Purwadi 2017 Pertumbuhan Dan Kadar Protein Pada Tanaman Kangkung Darat (Ipomoea reptans poir) Dengan Pemberian Pupuk Organik Cair (POC) Berbahan Dasar Sabut Kelapa Dan Limbah Cair Tahu. skripsi Progam Studi Pendidikan Biologi Fakultas Keguruan Dan Ilmu Pendidikan Universitas Muhammadiyah Surakarta.

Qiong Shi-T, Hui Peng, Si-Yu Zeng, Rong-Yu Ji, Kun Shi, He Huang, and Xiao-Jun Ji 2017 Microbial Production Of Plant Hormones: Opportunities And Challenges, J. Bioengineered 8 (2): $124-128$. . doi: $10.1080 / 21655979.2016 .1212138$
e-ISSN : 2621-7236

p-ISSN : 1858-134X

Rukmana, R. 1994. Kangkung. Kanisius. Yogyakarta. $44 \mathrm{hlm}$

Salisbury, F.B., dan C.W. Ross. 1995. Fisiologi tumbuhan jilid 3. ITB. Bandung. $343 \mathrm{hlm}$

Setiawan, 2005 Pemanfaatan Kotoran Kelinci Penebar Swadaya Jakarta

Sutanto, R. 2002. Penerapan Pertanian Organik. Kanisius. Yogyakarta. $232 \mathrm{hlm}$.

Sutejo. 2002. Pengaruh Pemupukan $K$ dan Frekuensi Pemberian Air Pada Beberapa Kultivar Kedelai (Glycine max l.) Terhadap Sifat Morfologi Perakaran Pertumbuhan Dan Hasil Tanaman. Fakultas Pertanian. UGM. Yogyakarta.

Suwasono, H., Wahono H.S dan M. Kurniati. 2001. Produksi Tanaman Dan Penanganan Pasca Panen. PT. Raja Grafindo Persada. Jakarta. 78 hlm.

Shyarifudin, I. 2014. Budidaya Hortikultura Kangkung. Diakses 5 desember 2017. Http:// worldmeco.wordpress.com/. $11 \mathrm{hlm}$

Yulipriyanto, h. 2010. Biologi tanah dan strategi pengelolaannya. Graha ilmu. Yogyakarta. $271 \mathrm{hlm}$ 